assistant lecturer in Prof. A. C. Hardy's new department there. Two years later, the department was enlarged to one of Zoology and Oceanography, and Mr. 'Espinasse then became lecturer with enlarged responsibilities on the zoological side. In 1942, when Prof. Hardy was appointed to the regius chair of natural history at Aberdeen, the Department was split into two: one of zoology with Mr. 'Espinasse as head (several departments in the College have non-professorial heads), and one of oceanography under Dr. C. E. Lucas. Zoology now again has a chair.

Prof. 'Espinasse is a versatile zoologist. While he is keenly interested in genetical theory and has written several papers on it, his researches have been mainly in the fields of micro-anatomy, embryology and the more physiological side of zoology. He worked out the development of the hypophysial portal system in man, has done much work on the action of the hormone ostrone and made important contributions to our knowledge of feather growth. While his skill as a microtomist has enriched his Department with beautiful series of histologieal and embryological preparations, he brings to his teaching something even more valuable: a love of discussion and a deep interest in the philosophy lying behind biologicalf theory.

\section{Centenary of Anzsthesia}

ON October 16, 1846, W. T. G. Morton, a dentist of Boston Maschusetts, successfully administered ether to a pared named Gilbert Abbot during an operation, forformed by J. C. Warren, for removal of tun fur from the neck; and this date has. just be Anelebrated as the anniversary of the first practical application of anæsthesia for the purpose of abolishing pain during a surgical operation. Ain editorial article in the British Medical Journal (p. 546, Oct. 12, 1946), and six other articles in this issue, mark this centenary and give an epitome of our knowledge of anæsthetics. Dr. J. H. Burn and H. G. Epstein discuss theories of anæsthetic action, Dr. C. Langton Hewer discusses the remarkable recent advances in anæsthetic practice, A. C. King contributes an illustrated article on the history of anæsthetic apparatus, and Dr. E. Ashworth Underwood, director of the Wellcome Historical Medical Museum, discusses, in another illustrated article, the history of man's knowledge of the use of substances for the purpose of abolishing pain. This latter article, which is a valuable contribution to the history of medicine, begins with a reference to the neolithic age, when unknown substances may have been used for the purpose of abolishing pain during the operation of trephining the skull, which appears to have been performed quite often in those times. The controversies which raged around the work of Clarke, Wells, Morton, and the others, and their experiences with nitrous oxide and ether, are here discussed. Chloroform, first used by James Young Simpson in Edinburgh, came a year or so later. Thereafter, the stage was set for the remarkable subsequent development of what Sir William Osler has called "medicine's greatest single gift". These developments are the subject of an exhibition at the Wellcome Historical Museum, which was opened by Lord Moran on October 16.

In two of the articles in the British Medical Journal we are reminded of the close relationships which have always existed between medicine and literature. It was Oliver Wendell Holmes who sug- gested the terms 'anæsthesia' and 'anæsthetic' ; and, when W. E. Henley, who had already lost one foot, had to have the other one amputated, he sought the aid of Lister and was under his care in the Edinburgh Old Infirmary during the years 1873-75. There, with the aid of what he has described as "the thick, sweet mystery of chloroform", he lost his other foot. In his "Hospital Verses", which are extensively quoted in this issue of the British Medical Journal in an article by Gunilla Liddle, he gives us a vivid picture, not only of Lister himself, but also of life in the wards of those days and of his own experiences in them. The centenary of the first practical use of anæsthetic substances has also been celebrated by a meeting, held on October 16, of the Royal Society of Medicine, and the British Medical Bulletin has a special issue devoted to anæsthetics which has the thoroughness and comprehensive scope characteristic of that journal.

\section{Research in Chronic Rheumatism}

As a result of/nvestigations begun so long ago as 1922, the Mediell Advisory Committee to the Ministry of Health rocommended in 1945 that a number of diagnostic and research centres should be established for the/study of chronic rheumatism and for the improrement of existing facilities for diagnosis and treatment; and it was proposed that the special centres should be located in university medical schools and teaching hospitals, where resources are available for a combined attack on the disease in all its forms. A rheumatism centre of the kind envisaged by the Ministry is to be established at the University of Manchester," with the assistance of a grant from the Nuffield Foundation of $£ 100,000$ spread over ten years. In broad outline it is proposed to establish a diagnostic and research centre at the teaching hospital, the Manchester Royal Infirmary, to deal with short-stay in-patients and out-patients. For long-stay in-patients there will also be a clinic at a base hospital near the centre, provided by the Manchester Public Health Committee, and a second base hospital, the Devonshire Royal Hospital at Buxton. At the base hospitals lengthy investigations will be carried out, and problems of rehabilitation and resettlement will be studied. At the centre the work will cover two main fields : the clinical, sociological and industrial aspects of the disease, and the fundamental study of the disease process by pathological, bacteriological and biochemical methods. The clinical work will be under the direction of a physician who will have the full co-operation of the Departments of Orthopædics and Physiotherapy of the Manchester Royal Infirmary as well as of the University Dental School. The social aspects of the disease, and its industrial implications, will be studied in co-operation with the University Department of Industrial Health. Fundamental research into the causes of diseases of the bones and joints will be under the direction of a whole-time pathologist who is an expert in this field.

National Laboratories in India
Accordinte to The Statesman (Calcutta and Delhi)
of Octobd 14, plans for four more national labora-
tories jh India have been approved recently by the
Govghing Body of the Council of Seientific and
Industrial Research.
Dr. Rajendra Prasad, Minister for Food and Agriculture, will lay the foundation stone of the Fuel Research Institute at Digwadih, near Dhanbad, on 
November 17. The capital cost of the Institute is estimated at Rs. 14 lakhs. Mr. C. Rajagopalachari, Minister for Industries and Supplies and President of the Council of Scientific and Industrial Research, will lay the foundation stone of the National Metallurgical Laboratory at Jamshedpur on November 19. The initial capital expenditure on this Laboratory will be about Rs. 43 lakhs. The foundation stone of the National Physical Laboratory in Delhi will be laid by Pandit Jawaharlal Nehru, vice-president, new Central Government, on January 4, 1947, during the Indian Science Congress session. The estimated cost of this Laboratory is about Rs. 40 lakhs. Mr. B. G. Kher, Premier of Bombay, will lay the foundation stone of the National Chemical Laboratory at Poona some time towards the end of January 1947. The Bombay Government recently agreed to the location of this Laboratory in Poona and the transference to the Council of the land required for this purpose. This Laboratory is expected to cost Rs. 35 lakhs.

\section{Manchester Federation of Scientific Societies \\ A Federatign of Scintific Societies has been formed in Lay. Ster enable the member societies to work 0 ; 1 matters of common interest. PuQ ard applied science are both strongly repre- sen 10 in the Eederation, which will provide a meeting ground for workers in both academic and techno-} logical fidds on the widest possible basis. The new body fill not in any way seek to take over any of tho activities which are the functions of the partripating societies. It will, however, assist the executives of these societies in arranging their meetings and discussions to the greatest advantage of the members, many of whom belong to several societies. A calendar will be issued twice a year giving a list and dates of all meetings to be held by the societies in the Manchester district. The wider activities of the Federation are yet to be planned in detail. It is already interesting itself in the provision of post-graduate and refresher courses in science, and in this matter will seek the collaboration of the University of Manchester and the technical colleges. It will also pay attention to the problem of bringing scientific matters to public attention in popular form.

A need long felt by the Manchester scientific workers, and, indeed, by those of other big centres, including London, is for a scientific centre of their own. The home of the Manchester Literary and Philosophical Society in George Street, which frequently gave hospitality to other societies, was destroyed by enemy action in 1940. The scientific societies of Manchester need a building with a lecture theatre, meeting and committee rooms, and some provision for bodily refreshment, and it is hoped, by working together, that they may be able to satisfy this need. The principal scientific and professional societies are supporting the Federation, of which Dr. C. J. T. Cronshaw, a director of Imperial Chemical Industries, Ltd., has accepted an invitation to be the first president. Mr. J. T. Marsh, of Tootal Broadhurst Lee Co., Ltd., is the present chairman of the com. mittee, and Dr. E. H. Rodd, of Imperial Chemical Industries, Ltd. (Dyestuffs Division), Blackley, is the honoray secretary.

\section{Documlent Copyifg prtwerofilm}

THE nlotogap copying of documents and of pub ished rhatter had attracted serious study in the United"States for some years before war risks directed attention in Great Britain to its value. Recent conferences, such as that organised by the Association of Special Libraries and Information Bureaux (Nature, 156, 24; 1945), have established clearly that photographic methods of reproduction will have many future parts to. play in the publication and duplication of documents of all types, whether for business purposes or as part of the scientific information services (see Nature, 157, 745; 1946. 158,$353 ; 1946$ ). 'Microfilm', that is, $35-\mathrm{mm}$. film coated with a fine-grained photographic emulsion and adapted to carry a series of images usually $24 \mathrm{~mm}$. $\times 16 \mathrm{~mm}$. or $24 \mathrm{~mm}$. $\times 32 \mathrm{~mm}$., is one of the media most commonly used for this purpose ; but its application has undoubtedly been hindered by the limited supply of suitable apparatus for copying the original documents or for reading the film record. Potential users of microfilm will therefore be interested in the announcement of a new documentrecording camera and (No. 3) microfilm reader and printer, made by Messrs. W. Watson and Sons, Ltd., of 313 High Holborn, London, W.C.1. The camera is a general-purpose machine which makes special provision for originals in book form and can tackle single documents up to 27 in. $\times 18$ in.; it has a magazine holding $200 \mathrm{ft}$. of film and is designed for speedy operation, with interlocked controls. In the reader, the projected image is viewed by transmission through a diffusing screen 12 in. $\times 12$ in. The activities of the British Standards Institution in this field should do much to stimulate the production and use of such equipment in Britain.

\section{Science To-day}

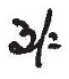

A WEEkLy science news-letter entitled Science To-day, edited by A. W. Haslett from 104 Clifton Hill, Longon, $Y$. Whend and and $30 \mathrm{~s}$. for 2 mo (50 issues), is intended to provide brief bet ace ate notes on the main trends in conthourary science for both the scientific and nonsUentific reader. It is intended to include also book reviews and notes on books. The first issue, dated October 10, consists of eight octavo pages and touches on fish migration, radar and surveying, the giant man of old Java (Meganthropus paleojavanicus), the international organisation of science, and lines of nuclear research on the atom. The latter article occupies three of the eight pages and is entitled "Atom Perspective"; it outlines in very general terms the structure of the atom, pointing out that we still know very little about the nucleus itself, which is the object of much current research.

Security in the Pacific Area

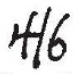

A REPORT by a Chatham House Study Group and issued by the 1 weis Institute of International Affairs, unfer fhentits "The Pattern of Pacific Security", poits 1 t fat the region is not in itself an area 1 hele possesses natural defining boundaries by which the political cartographer can almost automatically draw regional frontiers on the map of security. While there are certain interests and problems which are mainly Pacific in character, most of the Powers concerned in the region are also Powers with substantial interests elsewhere. Accordingly, the Pacific Ocean must be treated as an area which cannot be considered apart from others, and the whole argument of the report reinforces the view that a system of security in the Pacific can be established only on the wider basis of world organisation, the mainstays for which are the United. States, the British Common- 